\title{
A Case of Vitamin D Dependency Type I
}

\author{
Sayuri Matsumoto, Keiichi Ozono, Kanji Yamaoka, Katsusuke Yamamoto, \\ Shigeo Nakajima, Takehisa Yamamoto, Ken-ichi Satomura, Shintaro Okada, \\ Toshiyuki Yasuda and Yoshiki Seino \\ Department of Pediatrics, Osaka University, Osaka (S.M., K.O., K.Y., K.Y., S.N., T.Y., K.S., S.O.), \\ Department of Pediatrics, Chiba University, Chiba (T.Y.), \\ Department of Pediatrics, Okayama University, Okayama (Y.S.), Japan
}

\begin{abstract}
Vitamin D dependency type $\mathrm{I}$ is a disease characterized by hypocalcemia and rickets in early infancy. We report the case of a female patient diagnosed as having vitamin $\mathrm{D}$ dependency type I by the clinical features and the PTH loading test after a low calcium diet. The patient was referred to Osaka University Hospital when she was 2 years 2 months old. She had slight bowing of the legs but no hypocalcemia. Her serum concentrations of 25-hydroxyvitamin D $(25 \mathrm{OHD})$ and $1,25(\mathrm{OH})_{2} \mathrm{D}$ were $18.1 \mathrm{ng} / \mathrm{ml}$ and $14 \mathrm{pg} / \mathrm{ml}$, respectively. After 3 days on a low calcium diet, the PTH loading test was performed. Neither the low calcium diet nor the injection of PTH increased serum $1,25(\mathrm{OH})_{2} \mathrm{D}$ levels, while serum $1,25(\mathrm{OH})_{2} \mathrm{D}$ levels were significantly increased in normal controls. When active vitamin $\mathrm{D}$ metabolites were not administered, serum alkaline phosphatase (ALP) and PTH increased gradually to $1090 \mathrm{U} / 1$ and $1120 \mathrm{pg} / \mathrm{ml}$, respectively. After administration of a physiological dose $(0.08 \mu \mathrm{g} / \mathrm{kg} /$ day $)$ of $1 \alpha$-hydroxyvitamin $\mathrm{D}_{3}$ $\left(1 \alpha \mathrm{OHD}_{3}\right)$, the serum ALP and PTH levels returned to normal.

The blunted response of serum $1,25(\mathrm{OH})_{2} \mathrm{D}$ concentration to the $\mathrm{PTH}$ loading test as well as to the low calcium diet, and the necessity for a physiological dose of $1 \alpha \mathrm{OHD}_{3}$, suggest that she had a partial defect in renal $25 \mathrm{OHD}_{3}-1 \alpha$-hydroxylase activity.
\end{abstract}

Key words: vitamin D dependency type I , $1 \alpha$-hydroxylase, $1 \alpha \mathrm{OHD}_{3}$, Ellsworth-Howard test

\section{Introduction}

$1,25(\mathrm{OH})_{2} \mathrm{D}_{3}$ is a physiological vitamin $\mathrm{D}$ metabolite which has potent biological activity. $1,25(\mathrm{OH})_{2} \mathrm{D}_{3}$ is synthesized from 25 -

Received: April 9, 1992

Accepted: August 12, 1992

Correspondence: Kanji Yamaoka, M.D., Department of Pediatrics, Osaka University School of Medicine, 1-1-50 Fukushima, Fukusima-ku, Osaka 553 Japan hydroxyvitamin $\mathrm{D}_{3}\left(25 \mathrm{OHD}_{3}\right)$ in the kidney by $25 \mathrm{OHD}_{3}-1 \alpha$-hydroxylase ( $1 \alpha$-hydroxylase). 1 , $25(\mathrm{OH})_{2} \mathrm{D}_{3}$ binds its cognitive receptor in target cells and activates the receptor. Thereafter, the $1,25(\mathrm{OH})_{2} \mathrm{D}_{3}$-receptor complex binds specific DNA sequences, namely vitamin D responsive element $[1,2]$ in $1,25(\mathrm{OH})_{2} \mathrm{D}_{3}$ responsive gene promoter, and displays its biological activities.

Vitamin D dependency type I, first re- 
ported by Prader et al. [3] in 1961, is a disease characterized by hypocalcemia and rickets in early infancy. In this disease, a pharmacological dose of vitamin D or a physiological dose of active vitamin $\mathrm{D}$ metabolites is required to cure the hypocalcemia and rickets. This condition is transmitted in autosomal recessive form. Fraser et al. [4] reported in 1973 that $1 \alpha$-hydroxylase deficiency was associated with its pathogenesis. Subsequent studies indicated a new type of vitamin $\mathrm{D}$ resistant rickets where the disorder of $1,25(\mathrm{OH})_{2} \mathrm{D}_{3}$ receptor response in the target organ contributed to the pathogenesis $[5,6]$. This is called vitamin $\mathrm{D}$ dependency type II. Determination of serum $1,25(\mathrm{OH})_{2} \mathrm{D}$ levels appears to be the most reliable means for distinguishing the two disorders. The patient with vitamin $\mathrm{D}$ dependency type I shows a low serum $1,25(\mathrm{OH})_{2} \mathrm{D}$ level $(2-12 \mathrm{pg} /$ $\mathrm{ml}$ ) [7]; in contrast, vitamin $\mathrm{D}$ dependency type II shows high serum $1,25(\mathrm{OH})_{2} \mathrm{D}(66-916$ $\mathrm{pg} / \mathrm{ml})[8]$.

The complementary DNA for $1,25(\mathrm{OH})_{2} \mathrm{D}_{3}$ receptor was identified. This finding enables us to verify the diagnosis of vitamin $\mathrm{D}$ dependency type II, and several cases have been reported which were diagnosed by identification of point mutations $[9,10]$. There is no report at present in which the mutation of $1 \alpha$-hydroxylase in a patient with vitamin D dependency type $I$ is ascertained. In this paper, we have investigated the response of serum $1,25(\mathrm{OH})_{2} \mathrm{D}$ concentration after PTH loading and low calcium diet in a patient who was suspected to have vitamin $\mathrm{D}$ dependency type I, to confirm the pathogenesis of this type of vitamin $\mathrm{D}$ dependency.

\section{Case Report}

The high serum value of ALP was detected in a laboratory test before immunization, when the patient was 1 year 1 month old. $1 \alpha$-hydroxyvitamin $\mathrm{D}_{3}\left(1 \alpha \mathrm{OHD}_{3}\right)(0.06 \mu \mathrm{g} / \mathrm{kg} /$ day) was administered for a month, but did not normalize the serum ALP levels. She was then admitted to the Chiba University Hospital. On admission, she had slight bowing deformity of the legs, and rachitic change was evident in roentgenograms (Fig. 1. A). In laboratory data, hypocalcemia, hypophosphatemia, high levels of ALP and PTH, and generalized aminoaciduria were observed. She was tentatively diagnosed as vitamin $\mathrm{D}$ dependency type $\mathrm{I}$, and treated with $1 \alpha \mathrm{OHD}_{3}(0.1 \mu \mathrm{g} / \mathrm{kg} / \mathrm{day})$, after which these

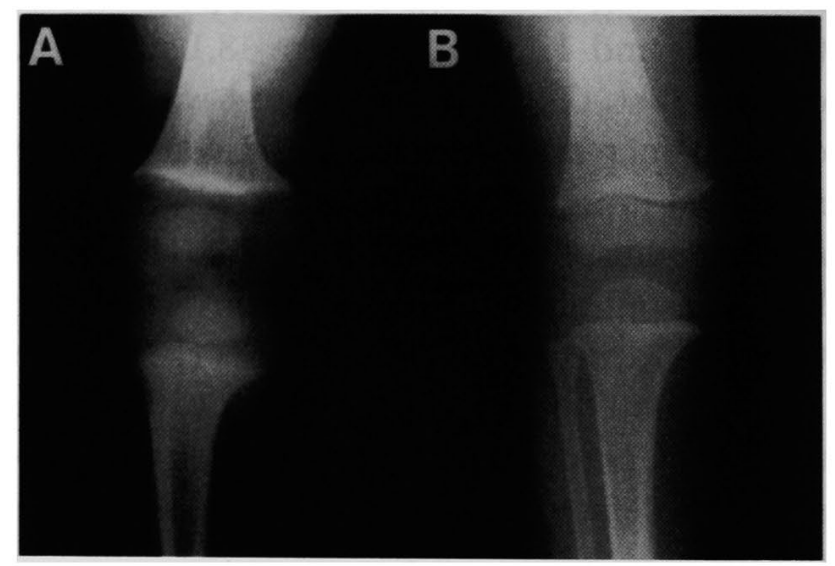

Fig 1. (A) Roentgenogram on admission at Chiba University Hospital. Rachitic changes including framing, widening, and cupping are seen in metaphyses of distal femur and proximal tibia. (B) Roentgenogram on admission at Osaka University Hospital. The rachitic changes are improved.

Table 1. Laboratory data on admission

\begin{tabular}{|c|c|c|c|c|c|}
\hline $\mathrm{TP}$ & $7.2 \mathrm{~g} / \mathrm{dl}$ & WBC & $11700 / \mathrm{mm}^{3}$ & $\mathrm{~m} \cdot \mathrm{PTH}$ & $426.6 \mathrm{pg} / \mathrm{ml}$ \\
\hline Alb & $2.6 \mathrm{~g} / \mathrm{dl}$ & $\mathrm{RBC}$ & $577 \times 10^{4} / \mathrm{mm}^{3}$ & intact-PTH & $67 \mathrm{pg} / \mathrm{ml}$ \\
\hline BUN & $16 \mathrm{mg} / \mathrm{dl}$ & $\mathrm{Hb}$ & $11.3 \mathrm{~g} / \mathrm{dl}$ & Serum cAMP & $42.7 \mathrm{pmol} / \mathrm{ml}$ \\
\hline $\mathrm{Cr}$ & $0.4 \mathrm{mg} / \mathrm{dl}$ & Serum $\beta_{2} \cdot \mathrm{MG}$ & $1.4 \mu \mathrm{g} / \mathrm{ml}$ & Urinary cAMP & $66.5 \mathrm{nmol} / \mathrm{mgCr}$ \\
\hline $\mathrm{Ca}$ & $9.6 \mathrm{mg} / \mathrm{dl}$ & Urinary $\beta_{2}-\mathrm{MG}$ & $134 \mu \mathrm{g} / 1$ & $250 \mathrm{HD}$ & $12.3 \mathrm{ng} / \mathrm{ml}$ \\
\hline $\mathrm{Ca}^{2+}$ & $1.22 \mathrm{mmol} / 1$ & Cer & $79.7 \mathrm{ml} / \mathrm{min} / 1.73 \mathrm{~m}^{2}$ & $1,25(\mathrm{OH})_{2} \mathrm{D}$ & $51 \mathrm{pg} / \mathrm{ml}$ \\
\hline $\mathrm{P}$ & $5.4 \mathrm{mg} / \mathrm{dl}$ & Blood gas & & $24,25(\mathrm{OH})_{2} \mathrm{D}$ & $0.45 \mathrm{ng} / \mathrm{ml}$ \\
\hline $\mathrm{Mg}$ & $2.0 \mathrm{mEq} / 1$ & $\mathrm{PH}$ & 7.46 & $\%$ TRP & $81.6 \%$ \\
\hline ALP & $534 \mathrm{U} / 1$ & $\mathrm{HCO}_{3}$ & $17.0 \mathrm{mEq} / 1$ & & \\
\hline GOT & $32 \mathrm{U} / 1$ & B.E. & -5.4 & & \\
\hline GPT & $4 \mathrm{U} / 1$ & & & & \\
\hline
\end{tabular}


abnormalities disappeared. She was then referred to Osaka University Hospital at 2 years 2 months of age. Her father's parents were first cousins. Her parents were healthy, and blood and urine tests did not indicate any abnormalities. Her height was $85 \mathrm{~cm}$ (-1SD) and her weight was $11.4 \mathrm{~kg}$ (-1SD). A slight bowing deformity was recognized in her lower extremities (Fig. 1. B), but no rachitic change was observed on radiographic examination. Table 1 shows the laboratory data on admission when $1 \alpha \mathrm{OHD}_{3}$ treatment had been stopped for 2 weeks. Serum ALP level was slightly elevated ( $534 \mathrm{U} / \mathrm{l})$, but serum calcium and phosphorus and renal function were within the normal ranges. Although the serum PTH was normal, plasma cAMP was increased and the value of \%TRP was decreased. Judging from the clinical course at Chiba University Hospital (Fig. 2), it appeared that the elevated serum ALP level and hyperparathyroid-function on admission to Osaka University Hospital might have been derived from subclinical hypocalcemia after the cessation of $1 \alpha \mathrm{OHD}_{3}$ treatment. Although the serum $25 \mathrm{OHD}$ and $1,25(\mathrm{OH})_{2} \mathrm{D}$ concentrations, which were measured using chick embryonal receptor as previously reported [11], were normal at that time, serum $1,25(\mathrm{OH})_{2} \mathrm{D}$ was decreased to $14 \mathrm{pg} / \mathrm{ml}$ after 3 weeks cessation of $1 \alpha \mathrm{OHD}_{3}$. These observations suggested that she had a disorder in $1 \alpha$-hydroxylase activity. To confirm this, we studied the serum $1,25(\mathrm{OH})_{2} \mathrm{D}$ concentration after the Ellsworth-Howard test (EH test) and a calcium restricted diet, because PTH and hypocalcemia are known to stimulate $1 \alpha$ hydroxylase activity [12].

\section{The Ellsworth-Howard test}

Before the $\mathrm{EH}$ test, a low calcium diet containing $200 \mathrm{mg}$ of calcium and $400 \mathrm{mg}$ of phosphorus was given for 3 days. Then 100 $\mathrm{U} / \mathrm{m}^{2}$ of 1-34 human PTH (Toyo Jozo) was infused intravenously, according to the guide-

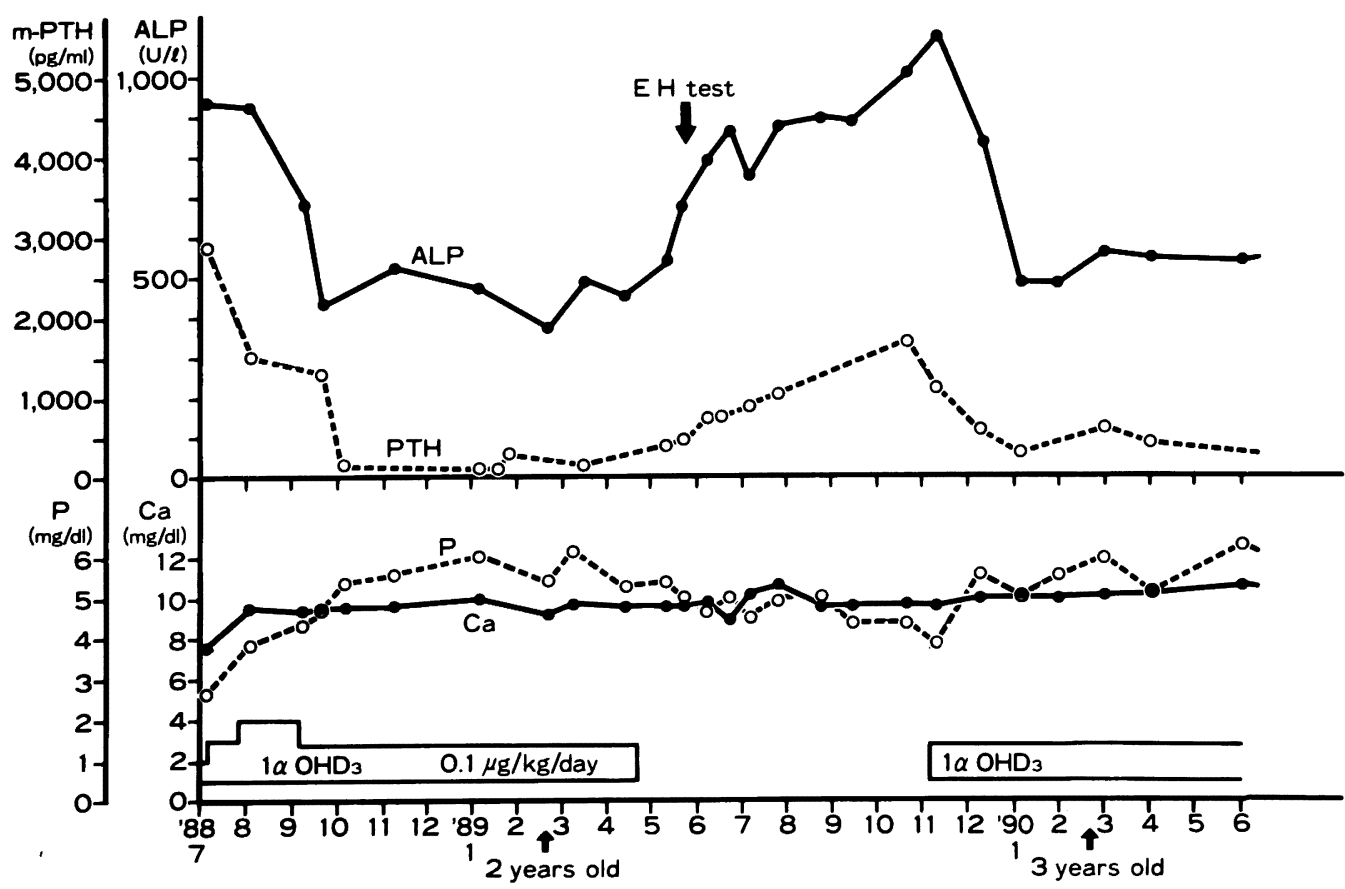

Fig 2. Clinical course since admission to Chiba University Hospital. Serum calcium, phosphorus, ALP and PTH levels returned to normal after administration of $1 \alpha \mathrm{OHD}_{3}(0.1$ $0.15 \mu \mathrm{g} / \mathrm{kg} /$ day). She was referred to Osaka University Hospital when she was 2 years 2 months old.

She was followed-up without any medication for 6 months to rule out vitamin D deficiency. Serum ALP and PTH increased to $1090 \mathrm{U} / \mathrm{l}$ and $1120 \mathrm{pg} / \mathrm{ml}$, respectively, and these values improved on administration of $1 \alpha \mathrm{OHD}_{3}(0.1 \mu \mathrm{g} / \mathrm{kg} /$ day $)$. 
lines of this provocation test [13]. There was a significant change in urinary cAMP excretion (15.3 times elevation at one hour after loading), although no significant changes were observed in the amount of renal phosphorus excretion (Fig. 3). Plasma cAMP levels also increased in response to the injection of PTH. Ishida et al. [14] pointed out that the change of plasma cAMP is a useful indicator for children in the EH test. They considered that more than $100 \mathrm{pmol} / \mathrm{ml}$ in the highest plasma cAMP value or an increment of more than $50 \mathrm{pmol} / \mathrm{ml}$ after PTH injection in the plasma cAMP was a positive reaction. The highest plasma cAMP of our patient was $376 \mathrm{pmol} / \mathrm{ml}$ and it increased by $357.6 \mathrm{pmol} /$ $\mathrm{ml}$ after PTH injection. From these results, we concluded that her response to exogenous PTH was normal. There were no significant changes in the serum $1,25(\mathrm{OH})_{2} \mathrm{D}$ concentration after 1-34 human PTH loading in the patient, while a $46 \%$ rise was observed in adult controls (Fig. 4).
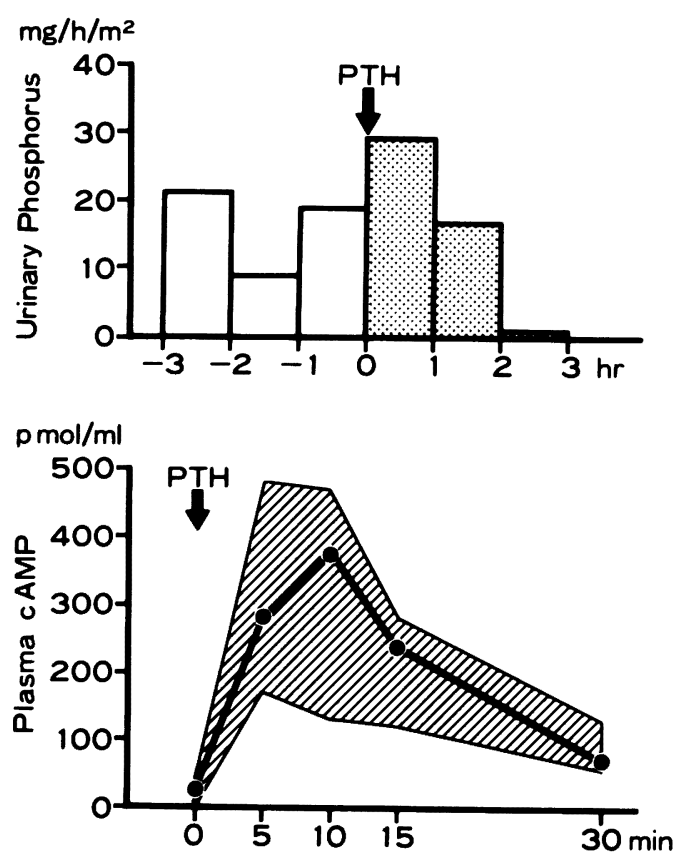

\section{Change of serum $1,25(\mathrm{OH})_{2} \mathrm{D}$ levels after low calcium diet}

Figure 5 shows the change of serum $1,25(\mathrm{OH})_{2} \mathrm{D}$ levels after 3 days on a low calcium diet containing $200 \mathrm{mg}$ of calcium and $400 \mathrm{mg}$ of phosphorus. Two patients diagnosed as idiopathic hypercalciuria were studied as controls. One was 4 years and the other 9 years old. In the patient with vitamin D dependency type I, there was no significant change in serum $1,25(\mathrm{OH})_{2} \mathrm{D}$ levels, while significant increases in serum $1,25(\mathrm{OH})_{2} \mathrm{D}$ concentration were observed in the controls.

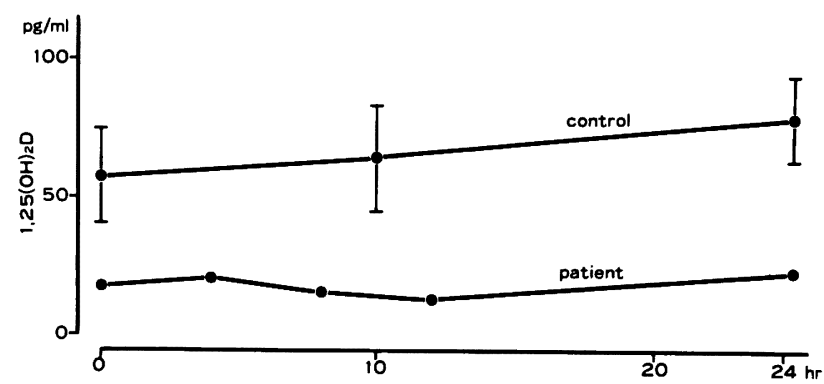

Fig 4. Time course of serum $1,25(\mathrm{OH})_{2} \mathrm{D}$ concentration after PTH injection. The values in ten adult volunteers are shown as the mean \pm SD.

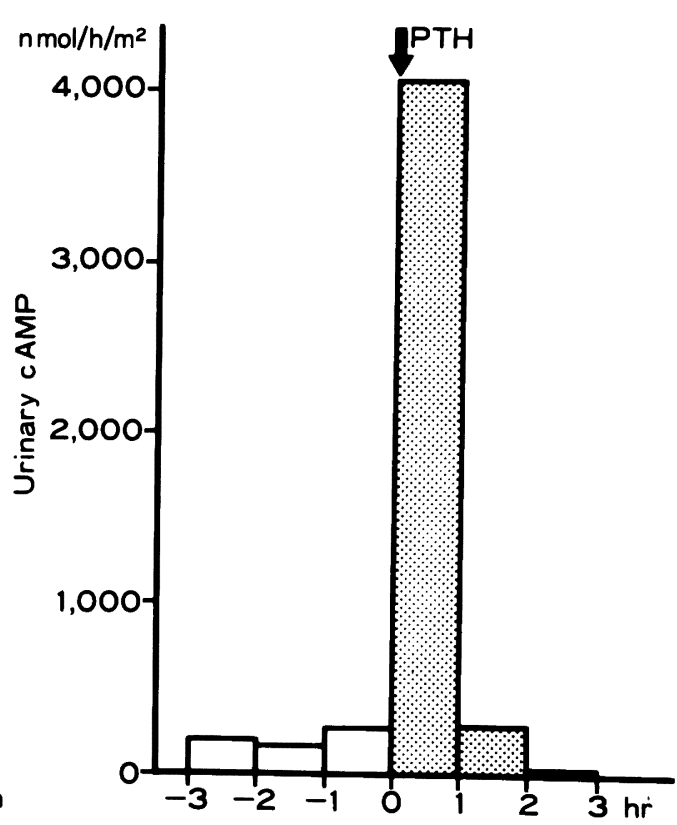

Fig 3. Result of Ellsworth-Howard test.

One hundred $\mathrm{U} / \mathrm{m}^{2}$ of 1-34 human PTH was infused intravenously. Changes of urinary phosphorus, urinary cAMP and plasma cAMP are shown. Open bars indicate values before PTH injection, and closed bars indicate those of urinary phosphorus and urinary cAMP after PTH injection. Shadow area represents the range of response of plasma
cAMP in the control. 


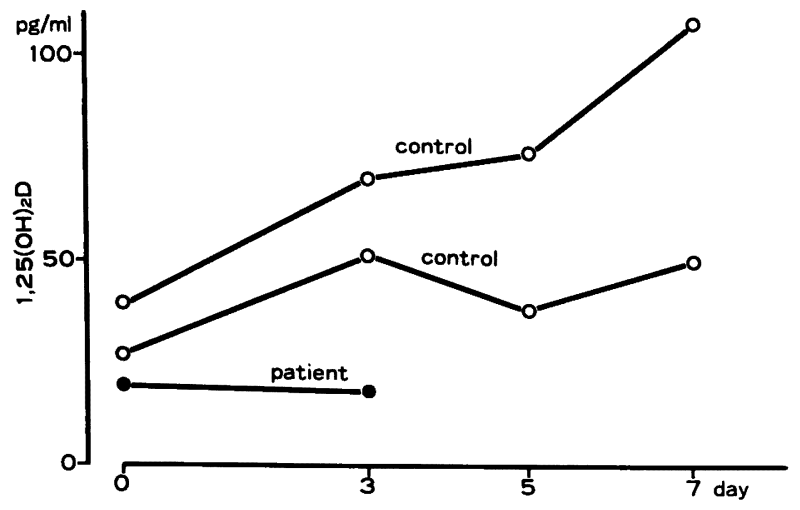

Fig 5. Serum $1,25(\mathrm{OH})_{2} \mathrm{D}$ concentration after 3 days on a low calcium diet containing $200 \mathrm{mg}$ of calcium and $400 \mathrm{mg}$ of phosphorus. Two patients with idiopathic hypercalciuria were studied as controls.

\section{Clinical course after discharge}

For the next 6 months, the patient was followed-up in our outpatient clinic without any medication to rule out transient vitamin $\mathrm{D}$ deficiency. Although the serum calcium level did not change, serum ALP and PTH increased and serum phosphorus decreased. After administration of $1 \alpha \mathrm{OHD}_{3}(0.08 \mu \mathrm{g} / \mathrm{kg} /$ day), the serum ALP, PTH, and phosphorus levels returned to normal (Fig. 2).

\section{Criteria of vitamin $D$ dependency type I}

Table 2 shows the revised criteria of vitamin D dependency type I [15]. Our patient satisfied all the criteria in paragraphs A and C.

\section{Discussion}

Vitamin D dependency type $\mathrm{I}$ is a rare inborn error of metabolism transmitted in autosomal recessive form. A deficiency of $1 \alpha$-hydroxylase, which involves the conversion of $25 \mathrm{OHD}_{3}$ to $1,25(\mathrm{OH})_{2} \mathrm{D}_{3}$, has been reported to explain the pathogenesis of this disease. The clinical and radiological features and biochemical data are similar to those of vitamin D-deficient rickets except for serum 250HD concentration. In our case, evidence of normal serum 25OHD concentration before medication and deterioration of serum ALP and PTH concentrations after cessation of a physiological dose of $1 \alpha \mathrm{OHD}_{3}$ exclude the diagnosis of vitamin D-deficient rickets.

Despite the consensus that the defect of $1 \alpha$-hydroxylase activity is the main abnormality in vitamin $\mathrm{D}$ dependency type $\mathrm{I}$ and the fact that it has been proved in pigs [16], there have been no reports which investigated it directly in humans. In this study, we tried to assess the $1 \alpha$-hydroxylase activity through the $\mathrm{EH}$ test and a low calcium diet, because PTH and a low calcium diet are known to stimulate this activity [17]. In the $\mathrm{EH}$ test and on a low calcium diet, there was no increase of serum $1,25(\mathrm{OH})_{2} \mathrm{D}$ level in our patient, while a significant increase was observed in controls. Although there was a good response of cAMP to $\mathrm{PTH}$, no phosphaturic effect was observed such as is seen in pseudohypoparathyroidism type II. This phenomenon, which was reported earlier in patients with vitamin D dependency type I [7], and in vitamin D deficient rats [18], is probably caused by secondary hyperparathyroidism.

In patients with vitamin $\mathrm{D}$ dependency type II, the clinical manifestations are similar to those of vitamin $\mathrm{D}$ dependency type $\mathrm{I}$. However, a high level of serum $1,25(\mathrm{OH})_{2} \mathrm{D}$ and the requirement of pharmacological doses of active vitamin $\mathrm{D}$ metabolites are thought to

Table 2. Vitamin D Dependency type I

Criteria for diagnosis

(A) Clinical characteristics

i ) Early onset

ii ) Rachitic change on roentgenogram

iii) Hypocalcemia

iv) Hyperalkalinephosphatasemia

v) Normal renal function

(B) Unsuccessful therapy

i ) 3000-4000 U of vitamin D p.o. every day for 4 weeks

(C) Successful therapy

i) Physiological dose of active vitamin D metabolites every day

(D) Others

i ) Low serum concentration of $1,25(\mathrm{OH})_{2} \mathrm{D}$

ii ) Function of renal tubules restored by administration of active vitamin D 
be useful to distinguish the two diseases. The serum $1,25(\mathrm{OH})_{2} \mathrm{D}$ concentration in our patient was in the low normal range through the follow-up period, and a physiological dose of $1 \alpha \mathrm{OHD}_{3}$ was sufficient to cure her rickets. Therefore we diagnosed her as vitamin D dependency type I .

Recently, linkage analysis using a large family of vitamin D dependency type I patients has demonstrated that the gene responsible for the disease is located on chromosome 12 at q14 [19]. Thus it may be possible in the future to detect carriers and to make an early diagnosis of vitamin D dependency type I before the onset of serious hypocalcemia.

\section{References}

1. Pike JW. Vitamin $\mathrm{D}_{3}$ receptors: Structure and function in transcription. Ann Rev Nutr 1991; 11: 189-216.

2. Ozono K, Sone T, Pike JW. The genomic mechanism of 1,25-dihydroxyvitamin $\mathrm{D}_{3}$. J Bone Miner Res 1991; 6: 1021-7.

3. Prader A, Illing R, Heierli H. Eine besondere Form der primären vitamin Dresistenten Rachitis mit Hypocalcämie und autosomal-dominantem Erbgang: die hereditäre Pseudo-Mangelrachitis. Helv Paediatr Acta 1961; 16: 452-68.

4. Fraser D, Kooh SW, Kind P, Holick MF, Tanaka Y, Deluca HF. Pathogenesis of hereditary vitamin $\mathrm{D}$ dependent rickets. An inborn error of vitamin $\mathrm{D}$ metabolism involving defective conversion of 25hydroxyvitamin $\mathrm{D}$ to $1 \alpha, 25$ - dihydroxyvitamin D. N Engl J Med 1973; 289: 817-22.

5. Tsuchiya $\mathrm{Y}$, Matsuo N, Cho H, Kumagai M, Yasaka A, Suda T, et al. An unusual form of vitamin D-dependent rickets in a child: Alopecia and marked end-organ hyposensitivity to biologically active vitamin D. J Clin Endocrinol Metab 1980; 51: 685-90.

6. Brooks MH, Bell NH, Love L, Stern PH, Orfei E, Queener SF, et al. Vitamin-D- dependent rickets type II, Resistance of target organs to 1,25-dihydroxyvitamin D. N Engl J Med 1978; 298: 996-9.

7. Delvin EE, Glorieux FH, Marie PJ, Pettifor JM. Vitamin D dependency: Replacement therapy with calcitriol. J Pediatr 1981; 99: 26-34.

8. Tsuchiya Y. Vitamin D dependency. Tanpakushitu Kakusan Koso 1988; 33: 87883.

9. Hughes MR, Malloy PJ, Kieback DG, Kesterson RA, Pike JW, Feldman D, et al. Point mutations in the human vitamin $D$ receptor gene associated with hypocalcemic rickets. Science 1988; 242: 1702-5.

10. Ritchie HH, Hughes MR, Thompson ET, Malloy PJ, Hochberg Z, Feldman D, et al. An ochre mutation in the vitamin $\mathrm{D}$ receptor gene causes hereditary 1,25. dihydroxyvitamin $\mathrm{D}_{3}$-resistant rickets in three families. Proc Natl Acad Sci USA 1989; 86: 9783-7.

11. Yamaoka K, Tanaka H, Kurose H, Shima $\mathrm{H}$, Ozono K, Nakajima S, et al. Effect of single oral phosphate loading on metabolites in normal subjects and in $\mathrm{X}$-linked hypophosphatemic rickets. Bone Miner 1989; 7: 159-69.

12. Lorence R, Tanaka Y, Deluca HF, Jones G. Lack of effect of calcitonin on the regulation of vitamin $\mathrm{D}$ metabolism in the rat. Endocrinology 1977; 100: 468-72.

13. Ogata E, Yamamoto $\mathrm{M}$, Matsumoto $\mathrm{T}$, Fujita T, Fukase M, Kinoshita $Y$, et al. Standard procedure and the diagnostic criteria for the Ellsworth-Howard test using human PTH (1-34). Folia Endocrinol Jap 1984; 60: 971-84.

14. Ishida M, Seino Y, Yamaoka K, Yabuuchi H, Okuno A, Matsuura N, et al. Standardization for evaluation of plasma cyclic AMP response in Ellsworth-Howard test. Clin Endocrinol (Tokyo) 1982; 10: 89-94.

15. Yamamoto M, Furukawa Y, Tamura Y, Seino Y, Igarashi Y, Fujita T, et al. Diagnostic criteria for pseudohypoparathyroidism and related disease. Folia Endocrinol Jap 1982; 58: 1080-94. 
Vit D Dependency Type I

16. Winkler I, Schreiner F, Harmeyer J. Absence of renal 25- hydroxycholecalciferol1-hydroxylase activity in a pig strain with vitamin D-dependent rickets. Calcif Tissue Int 1986; 38: 87-94.

17. Hughes MR, Brumbaugh PF, Haussler MR, Wergedal JE, Baylink DJ. Regulation of serum $1 \alpha, 25$-dihydroxyvitamin $\mathrm{D}_{3}$ by calcium and phosphate in the rat. Science 1975; 190: 578-80.
18. Au W, Raisz L. Restoration of parathyroid responsiveness in vitamin D-deficient by parenteral calcium or dietary lactose. J Clin Invest 1967; 46: 1572-1578.

19. Malgorzata L, Kenneth M, Glorieux FH. Mapping autosomal recessive vitamin $\mathrm{D}$ dependency type I to chromosome 12q14 by linkage analysis. Am J Hum Genet 1990; 47: 28-36. 